population; a previous report, however, suggests it is around $32 \%{ }^{20}$ Many of these unplanned pregnancies will be terminated; in our study the figure of $19 \%$ agrees with evidence to suggest that one in five pregnancies are terminated in the United Kingdom. ${ }^{21}$

\section{Conclusion}

The confused medical awareness of which contraceptive methods are appropriate may partly explain why advice to women with sickle cell disease is often lacking. We cannot exclude a possible risk of crises and thrombotic episodes with the use of the combined contraceptive pill. Despite this, we do not consider it to be contraindicated in this group of women as any complications should be balanced against the substantial risks of pregnancy. We feel that all methods of contraception may be considered in women with sickle haemoglobinopathies, though with appropriate caution.

We gratefully acknowledge generous financial support from SCAR (Sickle Cell Anaemia Relief) and the invaluable cooperation of the North London Haemoglobinopathy Group and the Sickle Cell Centres of north London.

1 Tuck SM, Studd JWW. Pregnancy in sickle cell disease in the UK. Br f Obstet Gynaecol 1983;90:112-7.

2 Foster HW. Contraceptives in sickle cell disease. South Med f 1981;74:543-5.

3 Evans DIK. Sickle cells and hormonal contraception. British foumal of

Family Planning 1984;10:80-1.
4 Perkins RP. Contraception for sicklers. N Engl f Med 1971;285:296.

5 Morrison JC. Hemoglobinopathies and pregnancy. Clin Obstet Gynecol 1979;22:819-42.

6 Louden N, ed. Handbook of family planning. 2nd ed. London: Churchill Livingstone, 1991

7 Sergeant GR. Sickle haemoglobin and pregnancy. BMJ 1983;287:628-30.

8 Petrou M, Modell B, Darr A, Old J, Kin E, Weatherall D. Antenatal diagnosis. How to deliver a comprehensive service in the United Kingdom. Ann N Y Acad Sci 1990;612:251-63.

9 Loukopoulos D, Hadji A, Papadakis M, Karababa P, Sinopoulou K, Boussiou $\mathrm{M}$, et al. Prenatal diagnosis of thalassaemia and of the sickle cell syndromes in Greece. Ann N Y Acad Sci 1990;612:226-36.

10 Anionwu EN, Patel N, Kanji G, Renges H, Brozovic M. Counselling fo prenatal diagnosis of sickle cell disease and thalassaemia major: a four year experience. I Med Genet 1987;25:769.

11 Rowley PT, Loader S, Sutera CJ, Walden M, Kozyra A. Prenatal screening for haemoglobinopathies. I. A prospective clinical trial. Am $f$ Hum Genet $1991 ; 48: 439-46$

12 Samuels-Reid JH, Scott RB, Brown WE. Contraceptive practices and reproductive patterns in sickle cell disease. I Natl Med Assoc 1984;76: 879-83.

13 Charache S, Niebl JR. Pregnancy and sickle cell disease. Clin Haemato 1985;14:729-46.

14 De Ceulaer K, Gruber C, Hayes R, Serjeant GR. Medroxyprogesterone acetate. and homozygous sickle cell disease. Lancet 1982;ii:229-31.

15 Freie HMP. Sickle cell diseases and hormonal contraception. Acta Obste Gynecol Scand 1983:62:211-7.

7. sickle cell disorders-fact or fiction? Clin Res 1986;34:217A.

17 Greenwald JG. Stroke in a woman with sickle cell trait taking oral contraceptoves. Conn Med 1971;35:231-2.

18 Hargus EP, Shearin R, Colon AR. Pulmonary embolism in a female adolescen with sickle cell trait and oral contraceptive use. Am $\mathcal{F}$ Obstet Gynecol 1977;129:697-9.

19 Haynes RL, Dunn JM. Oral contraceptives, thrombosis, and sickle cell haemoglobinopathies. IAMA 1967;200:186-8

20 Fleissig A. Unintended pregnancies and the use of contraception: changes from 1984 to 1989 . $B M$ F 1991;302:147.

21 Smith T. Unwanted pregnancies. BMF 1990;300:1154

(Accepted 8 April 1993)

\title{
Why have child pedestrian death rates fallen?
}

\author{
Ian Roberts
}

Pedestrian injuries are a leading cause of childhood mortality and disability. Over the past two decades in Britain child pedestrian death rates have fallen despite large increases in traffic volume. In this paper Roberts examines the likely reasons for this decline. He argues that neither prevention programmes nor improvements in medical care are a plausible explanation and that the decline is most likely the result of a substantial reduction in children's traffic exposure. He believes, however, that restricting children's traffic exposure exacerbates socioeconomic differentials in childhood mortality and denies children their right to mobility. Roberts is convinced that one answer is for British transport policy to be aimed at providing mobility equitably rather than struggling to meet the ever increasing demands of car travel.

Between 1980 and 1990 in England and Wales an average of 239 children were killed each year on the roads as pedestrians. For every death around 10 children required hospital admission for injuries. Pedestrian injuries were among the leading causes of childhood admission to intensive care facilities. ${ }^{2}$ Between $60 \%$ and $80 \%$ of these children have severe head injuries and are likely to experience long term disability. ${ }^{1}$

With the more widespread recognition of the public health importance of child pedestrian injuries in recent years several epidemiological studies have been mounted aimed at identifying modifiable risk factors. These studies have used case-control or cohort methods in an attempt to identify the factors which place some children at high risk of pedestrian injury. ${ }^{46}$ However, an effective public health response to the problem of child pedestrian injury demands that a second aetio- logical issue should be addressed. This concerns the identification of determinants of the incidence, attempting to understand why child pedestrian death rates change over time. Answering this question is likely to be as important as identifying risk factors, because if the determinants of the incidence could be identified it might be possible to control them, with gains for the whole child population. ${ }^{?}$

Over the past two decades child pedestrian death rates have fallen in many developed countries. In England and Wales between 1968 and 1987 the pedestrian mortality among children aged 0.4 years fell by $67 \%$, and among children aged $5-14$ years it fell by $39 \% .{ }^{8}$ To gain an insight into why child pedestrian death rates have fallen changes in the potential determinants of the child pedestrian death rate must be considered.

\section{Potential determinants of child pedestrian deaths}

The determinants of incidence are most readily identified when their prevalence changes abruptly. For this reason the effect of traffic volume on child pedestrian mortality was most evident during the energy crisis, when an increase in the price of petrol had a measurable effect on the growth in traffic volume. In New Zealand government restrictions on car use in the aftermath of the energy crisis effectively arrested the growth in traffic volume for seven years, during which there was a $46.4 \%$ reduction in child pedestrian mortality. ${ }^{9}$ Before this the death rate had been increasing in parallel with increasing traffic volumes. That the rate fell, as opposed to levelling off in line with traffic volume, suggests that there were other processes operating, tending to reduce the mortality, but which became evident only when traffic 
volume was unchanging. In Britain since 1968 the child pedestrian death rate has fallen despite an almost exponential increase in traffic volume (fig 1). This implies even more substantial changes in other, more powerful determinants of incidence. These changes have been particularly important for children aged 0.4 , for whom reductions in mortality have been most dramatic.

\section{PEDESTRIAN SKILIS TRAINING}

It would be comforting if there were evidence to show that at least some of the reduction in child pedestrian mortality could be attributed to pedestrian injury prevention programmes, but this evidence is lacking. In Britain the main thrust of preventive strategy has comprised efforts to improve child pedestrian behaviour through pedestrian skills training programmes-for example, "the Green Cross Code. However, data from evaluation studies suggest that these programmes are of limited value. ${ }^{10}$ Some North American studies have claimed reductions in injury rates following pedestrian education programmes but evaluation in these studies was based on before and after comparisons, so that the apparent reductions may have been confounded by changes in the background rate. ${ }^{112}$ Studies which have employed more rigorous methods have concluded that even large efforts to improve pedestrian behaviour are rewarded by only small gains. ${ }^{13}$ Furthermore, as programmes have been aimed predominantly at schoolchildren they cannot explain the large reduction in pedestrian mortality among preschool children. It therefore seems implausible that pedestrian education programmes have had a substantial effect on child pedestrian mortality.

In Britain between 1968 and 1987 the number of police reported child pedestrian casualties fell by $49 \%$ but the number of deaths fell by $61 \%$ J Broughton, Transport Research Laboratory, personal communication, 1992), suggesting that some of the decline in child pedestrian mortality may be due to a reduction in case fatality. These data must be viewed with caution; however. Child pedestrian injuries are significantly underreported in police accident databases, and changes over time in casualty nambers might simply reflect changes in the extent of underreporting. ${ }^{14}$ Furthermore, as children under 5 have a higher case fatality rate possibly the apparent overall reduction in case fatality is due to a change in the age distribution of injured children, young children now making up a smaller proportion of the total casualties. ${ }^{15}$. If there has been a reduction in case fatality this may have resulted from a decrease in injury severity or from improve- ments in medical care. Regardless, the $49 \%$ decrease in casualty numbers implies that most of the reduction in child pedestrian mortality is due to a reduction in collisions between child pedestrians and motor vehicles.

\section{TRAFFIC EXPOSURE}

The most plausible explanation for the downward trend in child pedestrian mortality is that it reflects a decline in children's traffic exposure. As the volume of road traffic has increased streets have become more dangerous and increasingly children have been kept away from them. ${ }^{16}$ Until recently the only testimony was old photographs or paintings depicting towns and cities as they were before the heyday of the motorcar, in which children would often be seen playing in the street. The urban landscapes of L S Lowry starkly portray the grime and pollution of industrial England, but the street scenes convey a vivacity and a sense of both safety and community which is absent today (fig 2).

A recent British study which examined changes in children's independent mobility over the past two decades has provided compelling evidence for a decline in children's traffic exposure. ${ }^{17}$ For example, it was found that whereas in $1971,80 \%$ of 7 and 8 year old English children were allowed to travel to school unaccompanied, in 1990 the figure was $9 \%$. The principal reason parents gave for their reluctance to allow their children to travel unaccompanied was traffic danger. Similarly, the age at which children receive parental "licence" to cross roads has increased considerably, and there was a pronounced decline in the proportion of children who were allowed to cross roads alone in 1990 compared with 1971. These findings might explain why the decline in pedestrian mortality has been least in the 5-14 year age group, as it would be more difficult for parents to limit the traffic exposure of older children. ${ }^{18}$ Moreover, a study in Manchester found that the pedestrian injury rate among children aged 11-14 had increased by $15 \%$ between 1969 and $1987 . .^{19}$

The importance of traffic exposure is also apparent in case centred epidemiological studies. A North American case-control study found that the absence of a play area adjacent to the home was associated with a fivefold increased risk of pedestrian injury (odds ratio $5 \cdot 3 ; 95 \%$ confidence interval $2 \cdot 6$ to $11 \cdot 0){ }^{4}$ The effect of this risk factor is likely to be mediated through the greater traffic exposure of children who have fewer alternatives to playing in the street.

\section{INDICES OF SAFETY}

A consideration of children's traffic exposure has been the missing element in virtually all of the political deliberations on road safety for children over the past two decades. ${ }^{17}$ As a result the effect on child pedestrian safety of the massive increase in traffic volume which has taken place over this period has been completely obscured. In the absence of an exposure measure the pedestrian injury rate has been used as an index of safety. The fallacy inherent in this reasoning is apparent from a consideration of age specific child pedestrian injury rates.

In the absence of information on traffic exposure, using pedestrian injury hospitalisation rates as a measure of safety would lead us to conclude that a 3 year old child (65.9/100000 admissions/year) is safer in a traffic setting than a 6 year old (68.9/100 000/year) (unpublished observations, New Zealand data). In contrast, for motor vehicle occupants the established safety measure is deaths per vehicle mile travelled, the rationale for which was given in the motor vehicle safety position paper of a recent American injury control conference-" "highway transportation has been 
created to facilitate mobility and mobility is of value. " ${ }^{20}$ Strategies which reduce the need for car travel or substitute car travel with safer forms of transport would substantially reduce population death rates. ${ }^{21}$ Thus deaths per vehicle mile travelled clearly signals that improvements in safety must not limit car use. Because children's mobility is not valued the decline in child pedestrian mortality has taken place at its expense.

\section{Implications of limiting child mobility}

As a means of preventing child pedestrian injuries limiting children's traffic exposure has powerful disadvantages. In particular, it will exacerbate the striking socioeconomic inequalities in child pedestrian injury morbidity and mortality that already exist. Both British and overseas studies have shown that poor children have a risk of pedestrian injury some three times greater than the least poor, and census area unemployment has been shown to be strongly correlated with census area child pedestrian injury rates. ${ }^{22-25}$ Indeed, pedestrian injuries are a major contributor to socioeconomic differentials in childhood mortality. ${ }^{22}$ As one third of British households do not have access to a car escorting children is likely to be far more difficult for some families. Poor children are likely to have fewer alternatives to playing in the street, and supervising children will be far more demanding in single parent families.

The British epidemiologist Geoffrey Rose has argued that in disease prevention two broad types of strategy can be distinguished: those that restore biological normality and those that take us further from the conditions for which we were genetically adapted. ${ }^{26}$ Restoration of biological normality is generally safe whereas the consequences of moving away from our biological condition are often unknown and the potential for harm may easily be overlooked. In this context limiting children's independent mobility is a clear departure from biological normality. Changes in childhood exercise patterns may impact on children's cardiovascular health, and with children increasingly confined to the home because of traffic danger heightened family tensions may erupt as family violence. Historically, public health investigators have been slow to recognise the importance of such social processes and as a result have witnessed the waxing and waning of mortality from many diseases, although often ignorant of the reasons and powerless to intervene. ${ }^{27}$

\section{The future}

Traffic volume is expected to increase by $142 \%$ by the year 2025, and no doubt the rampant individualism of free market economic policies will ensure that this prophecy is realised. ${ }^{28}$ The increase in traffic volume will inevitably result in a more hostile urban living environment for children. More fortunate children will reap the benefits of increased car travel while being largely immune from the accompanying dangers. But for the increasing number of British children living in poverty $^{29}$ paramount among threats to health are vehicles that most will only ever have the opportunity to steal. Further reductions in children's independent mobility may offset the increase in danger but already child pedestrian death rates seem to be levelling off and in some countries - for example, the United Statesmay be rising. ${ }^{8}$

It must be recognised that unfettered market forces will inevitably disregard the rights of the more vulner- able members in society and that a more collective social responsibility is appropriate. British transport policy should aim to provide mobility equitably and for all people rather than continually struggle to meet the ever increasing needs of car users. Of course, challenging the dominant position of the private passenger car in the transport system will inevitably confront powerful vested interests. The car lobby is strong and well organised. ${ }^{18}$ The lessons learnt from previous public health struggles with pecuniary power will be invaluable. ${ }^{30}$ Mobility is of value but so is equity. The transport system of the future should embrace both of these concerns.

1 Rivara FP. Child pedestrian injuries in the United States. Am 9 Dis Child 1990;144:692-6.

2 Roberts I, Streat S, Judson J, Norton R. Critical injuries in paediatric pedestrians. NZ Med f 1991;104:247-8.

3 Roberts I, Norton R, Hassall I. Child pedestrian injury 1978-87. N Z Med $\mathfrak{F}$ 1992;105:51-2.

4 Mueller BA, Rivara FP, Shyh-Mine L, Weiss NS. Environmental factors and the risk of childhood pedestrian-motor vehicle collision occurrence. Am f Epidemiol 1990;132:550-60.

5 Pless IB, Verreault $R$, Tenina $S$. A case control study of pedestrian and bicyclist injuries in childhood. Am $\mathcal{F}$ Public Health 1989;79:995-8.

6 Pless IB, Peckham CS, Power C. Predicting traffic injuries in childhood: a cohort analysis. I Pediatr 1989;115:932-8.

7 Rose G. Sick individuals and sick populations. Int $\mathcal{F}$ Epidemiol 1985;14:32-8.

8 Roberts I. International trends in pedestrian injury mortality. Arch Dis Child 1993;68:190-2.

9 Roberts I, Marshall R, Norton R. Child pedestrian mortality and traffic volume in New Zealand. BMF 1992;305:283.

10 Organisation for Economic Co-operation and Development. Traffic safety of children. Paris: OECD, 1983.

11 Preusser DF, Blomberg RD. Reducing child pedestrian accidents through public education. Fournal of Safety Research 1984;15:47-56.

12 Fortenberry JC, Brown DB. Problem identification, implementation and evaluation of a pedestrian safety programme. Accid Anal Prev 1982;14: 315-22.

13 Rivara FP, Booth CL, Bergman AB, Rogers LW, Weiss J. Prevention of pedestrian injuries to children: effectiveness of a school training program. Pediatrics 1991;88:770-5.

14 Maas MW, Harris S. Police recording of road accident inpatients. Accid Anal Prev 1984;16:167-84.

15 Pitt R, Guyer B, Hsieh C, Malek M. The severity of pedestrian injuries in children: an analysis of the pedestrian injury causation study. Accid Anal Prev 1990;22:549-59.

6 Adam JG. Risk homeostasis and the purpose of safety regulation. Ergonomics 1988;31:407-28.

17 Hillman M, Adams J, Whitelegg J. One false move: a study of children's independent mobility. London: Policy Studies Institure, 1991.

18 Quick A. Unequal risks: accidents and social policy. London: Socialist Health Association, 1991.

19 Preston B. Child pedestrian casualties with special reference to casualties on the journey to or from school in Manchester and Salford, England. on the journey to or from school

20 US Department of Health and Human Services. Third national injury control conference. Position papers. Washington, DC: US Government Printing Office, 1992

21 Trinca GW, Johnston IR, Campbell BJ, Haight FA, Knight PR, Mackay GM et al. Reducing traffic injury: a global challenge. Melbourne: Royal Australasian College of Surgeons, 1988

22 Office of Population Censuses and Surveys. Occupational mortality: child supplement. England and Wales 1979-80, 1982-83. London: HMSO, 1988. (Series DS No 8.)

23 Pless IB, Verreault R, Arsenault L, Frappier J, Stulginskas J. Am f Public Health 1987;77:358-60.

24 Dougherty G, Pless IB, Wilkins R. Social class and the occurrence of traffic injuries and deaths in urban children. Can $\mathcal{F}$ Public Health 1990;81:204-9.

25 Roberts I, Marshall R, Norton R, Borman B. An area analysis of child injury morbidity in Auckland. I Pediatr Child Health 1992;28:438-41.

26 Rose G. Strategy of prevention: lessons from cardiovascular disease. $B M F$ 1981;282:1847-51.

7 Rose G. Reflections on the changing times. BMF 1990;301:683-7.

28 Godlee F. Children harmed by traffic fumes. BMF 1991;303:329.

29 Spencer NJ. Child poverty and deprivation in the UK. Arch Dis Child 1991;66:1255-7.

30 Beaglehole R. Science, advocacy and health policy: lessons from the New Zealand tobacco wars. I Public Health Policy 1991;12:175-83.

(Accepted 25 March 1993)

\section{Correction}

How can we best prolong life? Benefits of coronary risk factor reduction in non-diabetic and diabetic subjects

A typesetting error occurred in table IV of this paper by John $S$ Yudkin (15 May, pp 1313-8). In the bottom line of the table (lowering systolic blood pressure $\geqslant 142 \mathrm{~mm} \mathrm{Hg}$ ) the entry in the second column of figures is wrong: it should read $0.38(-0.07$ to $1 \cdot 79)$, not $9 \cdot 83(-0.07$ to $1 \cdot 79)$. 